Acta Agroph., 2019, 26(3), 29-42

doi: $10.31545 /$ aagr/114397

\title{
VARIATION AND CORRELATION OF STARCH POTATO UTILITY FEATURES AND TUBER QUALITY TRAITS
}

\author{
Antoni Bombik@, Katarzyna Rymuza®, Tomasz Olszewski \\ Siedlce University of Natural Sciences and Humanities, \\ Faculty of Agrobioengineering and Animal Husbandry \\ ul. Prusa 14, 08-110 Siedlce \\ e-mail: antoni.bombik@uph.edu.pl
}

\begin{abstract}
In the study the authors used data from the Characteristics of the Polish National List of Potato Varieties concerning the economic value and the quality traits of starch potato varieties from the group of very early and early varieties and that of medium late and late varieties. For each of 13 quantitative traits, separately for every group of earliness, the basic statistical measures were determined and the coefficients of simple correlation were calculated, and for the utility traits - the equations of multiple linear regression. It was demonstrated that starch potato varieties were characterised by similar utility traits and variation in the case of dry matter content and starch content, tuber quality traits, i.e. shape and its regularity, and also the depth of the eyes. The late varieties produced a higher tuber yield and, consequently, a higher yield of dry matter, starch yield and bioethanol yield. In addition, a number of positive correlations were shown among the analysed utility traits, especially the tuber yield, with the tuber quality traits, i.e. starch yield, dry matter yield, bioethanol yield, and resistance to virus $\mathrm{Y}$. Negative correlations appeared only in the group of very early and early varieties, between dry matter yield and resistance to virus $\mathrm{Y}$ and the content of starch and resistance to common scab.

Keywords: starch potato, earliness group, variety, utility traits, quality traits, variation and correlation of traits
\end{abstract}

\section{INTRODUCTION}

The fundamental source of information on crop plant varieties in Poland is the descriptive list of crop plant varieties (Descriptive List of Varieties, crop plants 2016), varieties entered in the National List of Varieties (NLI), published by the Research Centre for Cultivar Testing (COBORU). It contains a lot of information on crop plant varieties based on numerous studies and experiments conducted by the Experimental Stations for Variety Testing (SDOO) in the diversified conditions of the country. In recent years, the NLI listed about 30 starch potato varieties. The 
large number of cultivars in the list has its advantages, the main one being the availability of information on the economic and utility traits of the cultivars, such as the total yield, yield structure, starch content, resistance to viruses, tuber morphology, consumer assessment etc. The large number of cultivars allows also better choice for production in relation to the adopted use direction, adapted to the local economic and agriculture-environmental conditions (Rembeza 2004).

The primary step in correct choice of cultivar is to determine the planned use of the tubers. Different traits are sought in edible potato tubers, in starch potato cultivars, and in tubers produced for processing (Rykaczewska 2010, Nowacki et al. 2013, Zarzecka 2014). Chemical components of tubers, affective their quality, are influenced by the cultivar factor and can be modified by the environment, both in the course of growth and in storage (Niderchauser 1993, Hertog et al. 1997, Zgórska and Frydecka-Mazurczyk 2000, Edwards et al. 2002). The most important traits of starch potato include the yield of tubers, starch content, starch yield, and stability of technological traits (Fontes et al. 2010, Zgórska i Grudzińska 2010). Tubers grown for processing, e.g. for starch production, should be free of deeper scars and deep eyes, as those will not be cleaned properly and soil residues will get into the end product, lowering its quality (Styszko et al. 2001).

The most important parameter for the group of starch potato cultivars is starch content which, according to the standard PN-75/R-74451, should be not less than $15 \%$. A lower content of that component is economically unprofitable both for the producers and for the processing companies, due to high costs of production and processing (Bombik and Wolska 2004, Mystkowska et al. 2016).

Starch yield is the product of the total yield and of the content of starch in tubers. The yield level of potato and the content of starch in tubers depend on the cultivar and on the cultivation technology applied (Roztropowicz 1993). The importance of those factors for the yield and for starch accumulation is not the same. Starch yield depends to a greater degree on correct cultivation technology than on genetic traits (Prośba-Białczyk 2008, Kołodziejczyk et al. 2013).

Potato varieties differ significantly in terms of starch content in tubers (Kamasa 2002). Cultivars with a higher leaf and tuber resistance to potato blight and to virus $\mathrm{Y}$ and to leafroll virus usually have a higher starch content (Styszko et al. 2001). No such relationship has been observed in the case of resistance to virus $M$, potato rhizoctoniosis, dry rot, common scab, and potato cyst nematode. It has been noted that the same potato cultivar grown in various environments has different levels of starch content. The main cause for such a differentiation, apart from climatic and cultivation technology effects, is the actual infestation of potato with plants with potato blight and viruses. Kołodziejczyk et al. (2013) report that starch content in potato tubers is a varietal trait, strongly modified by the spoil conditions, fertilisation level (especially with nitrogen), and by plant protection treatments. 
Starch potato quality traits are the following: size of starch granules and the chemical composition of starch. Currently, the starch processing industry pays less attention to the quality traits than to the utility features of starch potato cultivars. In addition, for a few decades now the starch quality features are neglected at the registration of potato cultivars. This situation causes that at present this subject-matter is not recognised (Styszko 2004, Zgórska and Grudzińska 2012, Bogucka 2014). The size of starch granules depends also on the soil conditions and on cultivation technology. There is a positive correlation between tuber size and starch granule size. With a rapid influx of assimilates to the tuber small starch granules are formed, and with a slower influx the granules are better developed. Fertilisation with phosphorus and potassium is conducive to the formation of larger granules, while nitrogen and organic fertilisation produces the opposite effect (Lewosz 1985, Leszczyński 2000, 2001, Jansen et al. 2001, Bach et al. 2013, Bogucka and Cwalina-Ambroziak 2016).

In food processing, the variability of raw material, i.e. differentiation of external and internal traits, requires the estimation of potato cultivars suitability immediately after the harvest. In the COBORU registry experiments, the suitability of potato cultivars for food processing is evaluated only in relation to the production of selected assortments (Zgórska and Grudzińska 2010, 2012). In starch potato production, the criteria of starch quality are less important than the criteria of starch content in tubers and starch yield. The main point here is starch content in tubers and starch yield, and in a majority of processing plants those parameters are the only ones to be taken into account in the choice of cultivar (Kamasa and Borys 1991, Styszko 2004, Bogucka et al. 2010, Bogucka 2014).

The objective of the study was the estimation of the variation and correlation of selected utility features and quality traits of starch potato tubers.

\section{MATERIAL AND METHOD}

The material for the study consisted of data published by the Plant Breeding and Acclimatisation Institute, National Research Institute in Radzików, Branch in Jadwisin, concerning the economic value and quality evaluation of starch potato cultivars from all earliness groups (Characteristics of the Polish National List of Potato Varieties 2016).

13 starch potato cultivars from the group of very early and early cultivars (Cedron, Boryna, Glada, Harpun, Jubilat, Kaszub, Kuba, Mieszko, Pasat, Rumpel, Szyper, Widawa and Zuzanna) and 13 cultivars from the group of medium late and late cultivars (Danuta, Ikar, Pasja Pomorska, Bzura, Gandawa, Hinga, Inwestor, Jasia, Kuras, Pokusa, Rudawa, Skawa and Sonda) were selected for the analysis. The following quantitative traits were selected for the estimation of variation and correlation: $X_{1}$ - total yield of tubers $\left(\mathrm{t} \mathrm{ha}^{-1}\right), \mathrm{X}_{2}-$ dry matter content $(\%), \mathrm{X}_{3}-$ dry matter yield $\left(\mathrm{t} \mathrm{ha}^{-1}\right), \mathrm{X}_{4}-$ starch content $(\%), \mathrm{X}_{5}-$ starch yield $\left(\mathrm{t} \mathrm{ha}^{-1}\right), \mathrm{X}_{6}-$ bioethanol yield $\left(1 \mathrm{ha}^{-1}\right), \mathrm{X}_{7}-$ resistance to 
virus $Y$ (scale 1-9, 1 - the lowest resistance, 9 - the highest resistance), $X_{8}$ - resistance to virus L (scale 1-9, 1 - the lowest resistance, 9 - the highest resistance), $X_{9}-$ resistance to potato blight (scale 1-9, 1 - the lowest resistance, 9 - the highest resistance), $X_{10}$ - resistance to common scab (scale 1-9, 1 - the lowest resistance, 9 - the highest resistance), $X_{11}$ - tuber size (scale 1-9, 1 - smallest tubers, 9 - largest tubers), $X_{12}$ - shape regularity (scale 1-9, 1 - irregular shape, 9 - highly regular shape), $X_{13}$ - depth of eyes (scale 1-9, 1 - very deep eyes, 9 - shallow eyes). In addition, also 2 quality traits were estimated, the colour of tuber flesh and the colour of tuber skin.

For each of the quantitative features 2 basic statistical measures were determined - arithmetic mean and coefficient of variation (quotient of standard deviation and arithmetic mean expressed in \%). In addition, the Pearson simple correlation coefficients were calculated, separately for the two groups of earliness, and multiple linear regression equations were determined, describing the following traits: total tuber yield, dry matter content, starch content and bioethanol yield. The goodness of fit of the equations to empirical data was assessed with the use of the coefficient of determination.

The method of statistical calculations was taken from the work by Trętowski and Wójcik (1991), and the statistical analysis was performed using the software STATISTICA 12.5.

\section{RESULTS AND DISCUSSION}

Among the 13 very early and early starch potato cultivars (Tab. 1), 2 cultivars were entered in the List the earliest: Harpun and Glada (in 1993 and 1994, respectively), and 3 cultivars were entered the latest: Szyper, Mieszko and Widawa (in 2014, 2015 and 2015, respectively). Among the 13 cultivars, as many as 12 were from Polish breeding, and among those 9 (ca. 70\%) from Pomorsko-Mazurska Hodowla Ziemniaka in Strzekęcino, 3 from Hodowla Ziemniaka Zamarte, and one from Europlant, a German plant breeding firm. Medium late and late starch potato was also represented by 13 cultivars, the earliest registered (in 1986) being cultivar Bzura, and the latest registered (in 2005, 2006, 2007 and 2009, respectively): Inwestor, Pokusa, Kuras and Danuta. The most, 11 cultivars, came from Polish breeding, including 6 cultivars (ca. 50\%) from PMHZ Strzekęcino, 4 from HZ Zamarte, and also one each from German (Bohm-Nordkartoffel Agrarproduktion $\mathrm{OHG}$ ) and Dutch (Agrico) breeding companies.

Tuber yields of all very early and early starch potato cultivars (Tab. 2) varied from somewhat above $34 \mathrm{t} \mathrm{ha}^{-1}$ (cv. Cedron) to nearly $50 \mathrm{t} \mathrm{ha}^{-1}$ (cv. Szyper). Dry matter content for all the cultivars exceeded $25 \%$, attaining as much as over $31 \%$ (cv. Pasat). Dry matter yield oscillated around the level of $10 \mathrm{tha}^{-1}$ (from $9.5 \mathrm{t} \mathrm{ha}^{-1}$ cv. Harpun, to $12.5 \mathrm{t} \mathrm{ha}^{-1}-\mathrm{cv}$. Szyper). Starch content was determined in the range 
from $18 \%$ (cv. Harpun at just over that value) to nearly $22 \%$ (cv. Pasat), which, at the obtained tuber yield, gave starch yields from over 6 tons (cv. Cedron) to above $10 \mathrm{t} \mathrm{ha}^{-1}$ (cv. Szyper). Studies by Prośba-Białczyk (2008), Kołodziejczyk et al. (2013) and Rymuza et al. (2015) indicate that starch yield is determined by tuber yield in the range from 72 to $92 \%$, and by starch content in tubers in the range from 14 to $15 \%$. Bioethanol yield varied from nearly $4000 \mathrm{l} \mathrm{ha}^{-1}$ in the case of cv. Cedron to over $60001 \mathrm{ha}^{-1}$ in the case of cv. Szyper. The lowest variation (slightly above $6 \%$ ) was characteristic of starch content and dry matter content, and the highest (12\% and slightly above) - of starch yield and bioethanol yield.

Table 1. Cultivars of starch potato, their year of registry and origin

\begin{tabular}{lcllll}
\hline $\begin{array}{c}\text { Very early } \\
\text { and early } \\
\text { cultivars }\end{array}$ & $\begin{array}{c}\text { Year of } \\
\text { registry }\end{array}$ & \multicolumn{1}{c}{$\begin{array}{c}\text { Breeder } \\
\text { (origin) }\end{array}$} & $\begin{array}{c}\text { Medium late and } \\
\text { late cultivars }\end{array}$ & $\begin{array}{c}\text { Year of } \\
\text { registry }\end{array}$ & $\begin{array}{c}\text { Breeder } \\
\text { (origin) }\end{array}$ \\
\hline Cedron & 1997 & HZ Zamarte & Danuta & 2009 & BNA, Germany \\
Boryna & 2012 & PMHZ Strzekęcino & Ikar & 1996 & PMHZ Strzekęcino \\
Glada & 1994 & PMHZ Strzekęcino & Pasja Pomorska & 2000 & PMHZ Strzekęcino \\
Harpun & 1993 & PMHZ Strzekęcino & Bzura & 1986 & HZ Zamarte \\
Jubilat & 2011 & PMHZ Strzekęcino & Gandawa & 2004 & HZ Zamarte \\
Kaszub & 2012 & PMHZ Strzekęcino & Hinga & 1996 & PMHZ Strzekęcino \\
Kuba & 1999 & HZ Zamarte & Inwestor & 2005 & PMHZ Strzekęcino \\
Mieszko & 2015 & PMHZ Strzekęcino & Jasia & 1999 & HZ Zamarte \\
Pasat & 2002 & PMHZ Strzekęcino & Kuras & 2007 & Agrico, Holland \\
Rumpel & 2000 & PMHZ Strzekęcino & Pokusa & 2006 & PMHZ Strzekęcino \\
Szyper & 2014 & PMHZ Strzekęcino & Rudawa & 2002 & HZ Zamarte \\
Widawa & 2015 & HZ Zamarte & Skawa & 2000 & HZ Zamarte \\
Zuzanna & 2007 & Europlant, Germany & Sonda & 2002 & PMHZ Strzekęcino \\
\hline
\end{tabular}

Table 2. Utility traits of very early and early cultivars of starch potato

\begin{tabular}{lcccccc}
\hline \multicolumn{1}{c}{ Cultivar } & $\begin{array}{c}\text { Total yield of } \\
\text { tubers }\left(\mathrm{t} \mathrm{ha}^{-1}\right)\end{array}$ & $\begin{array}{c}\text { Dry matter } \\
\text { content } \\
(\%)\end{array}$ & $\begin{array}{c}\text { Fry matter yield } \\
\left(\mathrm{t} \mathrm{ha}^{-1}\right)\end{array}$ & $\begin{array}{c}\text { Starch } \\
\text { content } \\
(\%)\end{array}$ & $\begin{array}{c}\text { Starch } \\
\text { yield } \\
\left(\mathrm{t} \mathrm{ha}^{-1}\right)\end{array}$ & $\begin{array}{c}\text { Bioethanol } \\
\text { yield } \\
\left(1 \mathrm{ha}^{-1}\right)\end{array}$ \\
\hline Cedron & 34.2 & 28.9 & 9.9 & 18.4 & 6.3 & 3889 \\
Boryna & 39.9 & 26.1 & 10.4 & 20.3 & 8.1 & 5006 \\
Glada & 40.5 & 25.2 & 10.2 & 17.9 & 7.2 & 4931 \\
Harpun & 37.1 & 25.6 & 9.5 & 18.2 & 6.8 & 4427 \\
Jubilat & 43.6 & 25.2 & 11.0 & 19.4 & 8.5 & 5987 \\
Kaszub & 37.0 & 27.0 & 10.0 & 21.2 & 7.8 & 4821 \\
Kuba & 43.7 & 27.0 & 11.8 & 19.8 & 8.7 & 5239 \\
Mieszko & 42.8 & 26.0 & 11.1 & 20.0 & 8.6 & 4253 \\
Pasat & 38.4 & 31.1 & 11.9 & 21.8 & 8.4 & 4533 \\
Rumpel & 41.4 & 25.6 & 10.6 & 19.2 & 7.9 & 4708 \\
Szyper & 48.5 & 25.8 & 12.5 & 21.1 & 10.2 & 6138 \\
Widawa & 41.6 & 25.7 & 10.7 & 19.6 & 8.2 & 5006 \\
Zuzanna & 45.5 & 26.2 & 11.9 & 18.6 & 8.5 & 5315 \\
Arithmetic mean & 41.09 & 26.57 & 10.88 & 19.65 & 8.09 & 4942.5 \\
Coefficient of & 9.42 & 6.33 & 8.41 & 6.20 & 12.00 & 12.85 \\
variation (\%) & & & & & &
\end{tabular}


Table 3. Utility traits of medium late and late cultivars of starch potato

\begin{tabular}{lcccccc}
\hline \multicolumn{1}{c}{ Cultivar } & $\begin{array}{c}\text { Total yield of } \\
\text { tubers }\left(\mathrm{t} \mathrm{ha}^{-1}\right)\end{array}$ & $\begin{array}{c}\text { Dry matter } \\
\text { content }(\%)\end{array}$ & $\begin{array}{c}\text { Dry matter } \\
\text { yield }\left(\mathrm{t} \mathrm{ha}^{-1}\right)\end{array}$ & $\begin{array}{c}\text { Starch } \\
\text { content }(\%)\end{array}$ & $\begin{array}{c}\text { Starch yield } \\
\left(\mathrm{t} \mathrm{ha}^{-1}\right)\end{array}$ & $\begin{array}{c}\text { Bioethanol } \\
\text { yield }\left(\mathrm{ha}^{-1}\right)\end{array}$ \\
\hline Danuta & 50.4 & 24.3 & 12.2 & 18.5 & 9.3 & 5762 \\
Ikar & 35.4 & 28.8 & 10.2 & 22.2 & 7.9 & 4857 \\
Pasja Pomorska & 44.5 & 25.4 & 11.3 & 18.4 & 8.2 & 5445 \\
Bzura & 48.0 & 25.9 & 12.4 & 19.2 & 9.2 & 5696 \\
Gandawa & 40.5 & 25.3 & 10.2 & 17.9 & 7.2 & 4756 \\
Hinga & 40.0 & 27.6 & 11.0 & 20.0 & 8.0 & 5463 \\
Inwestor & 41.8 & 24.3 & 10.2 & 18.0 & 7.5 & 5218 \\
Jasia & 46.9 & 25.5 & 12.0 & 18.3 & 8.6 & 5536 \\
Kuras & 50.8 & 26.5 & 13.5 & 19.3 & 9.8 & 6059 \\
Pokusa & 44.0 & 23.0 & 10.1 & 16.5 & 7.3 & 5031 \\
Rudawa & 38.7 & 32.5 & 12.6 & 21.5 & 8.3 & 5142 \\
Skawa & 45.3 & 29.4 & 13.3 & 21.6 & 9.8 & 6047 \\
Sonda & 51.7 & 25.4 & 13.1 & 19.6 & 10.1 & 6263 \\
Arithmetic mean & 44.46 & 26.45 & 11.70 & 19.31 & 8.55 & 5482.7 \\
Coefficient of & 11.34 & 9.64 & 10.86 & 8.60 & 11.65 & 8.65 \\
variation (\%) & & & & & &
\end{tabular}

The medium late and late starch potato cultivars had more favourable utility features (Tab. 3) compared to the early cultivars. Tuber yield of the highest yielding cultivars (Danuta, Kuras and Sonda) exceeded $50 \mathrm{t} \mathrm{ha}^{-1}$, dry matter content was higher than $32 \%$ (cv. Rudawa), dry matter yield was over $13 \mathrm{t} \mathrm{ha}^{-1}$ (cv. Kuras, Skawa and Sonda), starch content over $22 \%$ (cv. Ikar), and starch yield above $10 \mathrm{t} \mathrm{ha}^{-1}$ (cv. Sonda), while bioethanol yield was above $62001 \mathrm{ha}^{-1}$ (cv. Sonda). The lowest variation (slightly above $8.5 \%$ ) was characteristic of starch content and bioethanol yield, and the highest (over 11.0\%) - of the total tuber yield and starch content.

Table 4. Resistance to diseases of very early and early cultivars of starch potato

\begin{tabular}{lcccc}
\hline \multicolumn{1}{c}{ Cultivar } & $\begin{array}{c}\text { Virus Y (PVY) } \\
\left(1-9^{\circ}\right)^{1 /}\end{array}$ & $\begin{array}{c}\text { Virus L (PLRV) } \\
\left(1-9^{\circ}\right)^{1 /}\end{array}$ & $\begin{array}{c}\text { Potato blight } \\
\left(1-9^{\circ}\right)^{1 /}\end{array}$ & $\begin{array}{c}\text { Common scab } \\
\left(1-9^{\circ}\right)^{1 /}\end{array}$ \\
\hline Cedron & 6.5 & 6.5 & 3.0 & 6.0 \\
Boryna & 7.0 & 7.0 & 5.5 & 5.5 \\
Glada & 7.0 & 5.5 & 5.0 & 6.0 \\
Harpun & 7.0 & 7.0 & 4.0 & 6.0 \\
Jubilat & 7.0 & 5.5 & 5.0 & 6.0 \\
Kaszub & 7.0 & 7.0 & 5.0 & 5.5 \\
Kuba & 9.0 & 6.5 & 5.0 & 6.0 \\
Mieszko & 8.0 & 6.5 & 6.0 & 5.0 \\
Pasat & 9.0 & 5.0 & 5.0 & 5.0 \\
Rumpel & 9.0 & 6.5 & 5.0 & 5.5 \\
Szyper & 8.0 & 5.5 & 5.0 & 5.5 \\
Widawa & 9.0 & 6.0 & 6.0 & 5.5 \\
Zuzanna & 9.0 & 5.5 & 3.0 & 7.0 \\
Arithmetic mean & 7.88 & 6.15 & 4.81 & 5.73 \\
Coefficient of & 12.72 & 11.19 & 19.70 & 9.16 \\
variation (\%) & & & & \\
\hline
\end{tabular}

${ }^{1 /}$ - explanation of the 1-9 scale in Material and Method. 
The early cultivars, similarly to the late ones, were characterised by similar mean values of all analysed traits, except for resistance to potato blight (Tab. 4 and 5). Whereas, the resistance of the individual cultivars from the different groups of earliness was varied. Resistance to virus $\mathrm{Y}$ varied from 6.5 to $9.0^{\circ}$, to common scab from 4.5 to $7.0^{\circ}$, to virus $\mathrm{L}$ from 3.5 to $7.0^{\circ}$. The late cultivars were more resistant to potato blight (from 4.0 to $8.0^{\circ}$, with a mean of $6.23^{\circ}$ ) than the early ones (from 3.0 to $6.0^{\circ}$, with a mean of $4.81^{\circ}$ ). In the case of the very early cultivars, the lowest variation was characteristic of resistance to common scab $(9.16 \%)$ and the highest of resistance to potato blight (19.70\%), while in the case of the medium late and late cultivars, the least variable was resistance to virus $\mathrm{Y}(10.37 \%)$, and the most variable was resistance to potato blight and to virus L (18.99\% and $19.49 \%$, respectively).

Table 5. Resistance to diseases of medium late and late cultivars of starch potato

\begin{tabular}{lcccc}
\hline \multicolumn{1}{c}{ Cultivar } & $\begin{array}{c}\text { Virus Y (PVY) } \\
\left(1-9^{\circ}\right)^{1 /}\end{array}$ & $\begin{array}{c}\text { Virus L (PLRV) } \\
\left(1-9^{\circ}\right)^{1 /}\end{array}$ & $\begin{array}{c}\text { Potato blight } \\
\left(1-9^{\circ}\right)^{1 /}\end{array}$ & $\begin{array}{c}\text { Common scab } \\
\left(1-9^{\circ}\right)^{1 /}\end{array}$ \\
\hline Danuta & 9.0 & 5.5 & 5.0 & 5.0 \\
Ikar & 7.0 & 5.5 & 5.5 & 7.0 \\
Pasja Pomorska & 8.0 & 7.0 & 5.0 & 6.0 \\
Bzura & 9.0 & 5.0 & 8.0 & 5.0 \\
Gandawa & 8.0 & 6.5 & 6.5 & 5.0 \\
Hinga & 9.0 & 5.5 & 7.0 & 5.5 \\
Inwestor & 7.0 & 5.5 & 7.0 & 6.0 \\
Jasia & 9.0 & 7.0 & 6.0 & 5.0 \\
Kuras & 9.0 & 3.5 & 8.0 & 6.0 \\
Pokusa & 7.0 & 5.5 & 4.0 & 5.0 \\
Rudawa & 9.0 & 6.5 & 6.0 & 5.0 \\
Skawa & 9.0 & 7.0 & 6.0 & 5.5 \\
Sonda & 9.0 & 4.0 & 7.0 & 4.5 \\
Arithmetic mean & 8.38 & 5.69 & 6.23 & 5.42 \\
Coefficient of & 10.37 & 19.49 & 18.99 & 12.40 \\
variation (\%) & & & & \\
\hline
\end{tabular}

${ }^{1 /}$ - explanation of the 1-9 scale in Material and Method.

Tubers of the very early and early cultivars of starch potato (Tab. 6) were highly varied in terms of most of the analysed traits. Tuber size, expressed in degrees of the 9-degree scale, varied from 5.5 (cv. Glada and Harpun) to $8.0^{\circ}$ (cv. Boryna, Pasat and Widawa). Most frequently, tuber shape was rounded-oval (oow), and only 3 cultivars: Boryna, Kaszub and Widawa had tubers with rounded shape (o). All the cultivars were characterised by similar tuber shape regularity (from $6.0-\mathrm{cv}$. Harpun, to $7.0^{\circ}-\mathrm{cv}$. Cedron, Kuba and Widawa, and 7.3 $-\mathrm{cv}$. Kaszub) and eye depth (from 6.0 - cv. Glada and Harpun, to $6.9^{\circ}-\mathrm{cv}$. Jubilat and Kaszub). The dominant colour of tuber flesh was yellow and creamy, and only in the case of 2 cultivars: Boryna and Rumpel it was white. Those cultivars most often had tuber skin coloured yellow, less frequently beige and red. 
Table 6. Traits of tubers of very early and early cultivars of starch potato

\begin{tabular}{|c|c|c|c|c|c|c|}
\hline Cultivar & $\begin{array}{c}\text { Tuber size } \\
\left(1-9^{\circ}\right)^{1 /}\end{array}$ & $\begin{array}{l}\text { Tuber } \\
\text { shape }^{2 /}\end{array}$ & $\begin{array}{l}\text { Shape } \\
\text { regularity } \\
\left(1-9^{\circ}\right)^{1 /}\end{array}$ & Flesh colour & Skin colour & $\begin{array}{l}\text { Eye depth } \\
\left(1-9^{\circ}\right)^{1 /}\end{array}$ \\
\hline Cedron & 7.5 & oow & 7.0 & 1.yellow-yellow & yellow & 6.5 \\
\hline Boryna & 8.0 & o & 6.5 & white & red & 6.2 \\
\hline Glada & 5.5 & o-oow & 6.5 & light yellow & yellow & 6.0 \\
\hline Harpun & 5.5 & o-oow & 6.0 & creamy & yellow & 6.0 \\
\hline Jubilat & 7.0 & o-oow & 6.9 & creamy & light beige & 6.9 \\
\hline Kaszub & 7.0 & o & 7.3 & creamy & yellow & 6.9 \\
\hline Kuba & 7.0 & oow & 7.0 & 1.yellow-yellow & yellow & 6.7 \\
\hline Mieszko & 6.5 & oow & 6.5 & light yellow & yellow & 6.5 \\
\hline Pasat & 8.0 & oow & 6.5 & creamy & yellow & 6.6 \\
\hline Rumpel & 7.0 & oow & 6.5 & White & light red & 6.1 \\
\hline Szyper & 7.5 & oow & 6.6 & light yellow & light beige & 6.8 \\
\hline Widawa & 8.0 & o & 7.0 & creamy & yellow & 6.4 \\
\hline Zuzanna & 7.0 & oow & 7.0 & light yellow & yellow & 6.4 \\
\hline Arithmetic mean & 7.04 & - & 6.72 & - & - & 6.46 \\
\hline $\begin{array}{l}\text { Coefficient of } \\
\text { variation }(\%)\end{array}$ & 11.77 & - & 5.19 & - & - & 4.92 \\
\hline
\end{tabular}

Table 7. Traits of tubers of medium late and late cultivars of starch potato

\begin{tabular}{lcccccc}
\hline \multicolumn{1}{c}{ Cultivar } & $\begin{array}{c}\text { Tuber size } \\
\left(1-9^{\circ}\right)^{1 /}\end{array}$ & $\begin{array}{c}\text { Tuber } \\
\text { shape }\end{array}$ & $\begin{array}{c}\text { Shape } \\
\text { regularity } \\
\left(1-9^{\circ}\right)^{1 /}\end{array}$ & Flesh colour & $\begin{array}{c}\text { Skin } \\
\text { colour }\end{array}$ & $\begin{array}{c}\text { Eye depth } \\
\left(1-9^{\circ}\right)^{1 /}\end{array}$ \\
\hline Danuta & 8.0 & oow & 7.3 & yellow & yellow & 7.6 \\
Ikar & 6.5 & oow & 5.5 & creamy-l.yellow & yellow & 5.5 \\
Pasja Pomorska & 6.0 & o & 7.0 & dark yellow & yellow & 6.7 \\
Bzura & 7.0 & oow-ow & 6.5 & light yellow & yellow & 6.0 \\
Gandawa & 8.0 & ow & 6.5 & creamy & yellow & 6.8 \\
Hinga & 5.5 & oow & 6.0 & light yellow & yellow & 5.5 \\
Inwestor & 6.0 & oow & 6.5 & creamy & yellow & 6.5 \\
Jasia & 7.0 & o-oow & 6.5 & yellow & yellow & 6.1 \\
Kuras & 9.0 & ow & 6.5 & creamy & yellow & 6.2 \\
Pokusa & 8.0 & oow & 6.8 & yellow & yellow & 7.0 \\
Rudawa & 7.0 & ow & 6.5 & creamy & yellow & 6.8 \\
Skawa & 7.0 & oow & 7.0 & yellow & yellow & 6.7 \\
Sonda & 7.0 & o & 6.5 & white & yellow & 6.7 \\
Arithmetic mean & 7.08 & - & 6.55 & - & - & 6.47 \\
Coefficient of & 13.79 & - & 6.91 & - & - & 9.20 \\
variation (\%) & & - & & - & - & \\
\hline
\end{tabular}

1/ - explanation of the 1-9 scale in Material and Method; ${ }^{2 /}$ - o-rounded, ow-oval, oow - rounded-oval.

In terms of the analysed traits, tubers of the medium late and late potato cultivars (Tab. 7) varied to a small extent, with the exception of tuber size. The smallest tubers (5.5 in the $9^{\circ}$ scale) were characteristic of cv. Hinga, and the largest tubers - of cv. Kuras. Tuber shape was most often oval (ow) and rounded-oval (oow), and 
only 2 cultivars (Pasja Pomorska and Sonda) had tubers with rounded shape (o). Similar for all the cultivars was the regularity of tuber shape (from 5.5 for cv. Ikar to $7.3^{\circ}$ for cv. Danuta) and the depth of eyes (from $5.5 \mathrm{for} \mathrm{cv}$. Ikar and Hinga to $7.6^{\circ}$ for $\mathrm{cv}$. Danuta). Tuber flesh colour from yellow to creamy dominated, and only one cultivar, Sonda, had white flesh. All the cultivars had yellow skin colour.

Tables 2-7 allow to compare the mean values and the variation of the utility features and tuber traits of the early and late cultivars. The late cultivars were characterised by a higher total yield of tubers compared to the early cultivars (by about $3.4 \mathrm{t} \mathrm{ha}^{-1}$ ), dry matter yield (by ca. $0.8 \mathrm{t} \mathrm{ha}^{-1}$ ), starch yield (by about $0.5 \mathrm{tha}^{-1}$ ), and bioethanol yield (by about 540 litres per hectare). This confirms the tendency for cultivars with a longer vegetation period to be potentially higher-yielding and to have a higher content of dry matter and starch than cultivars that ripen earlier (Prośba-Białczyk 2008, Kołodziejczyk et al. 2013, Trawczyński 2016). The variation of the utility traits of the analysed starch potato cultivars, measured with the value of the coefficient of variation, was at a similar level within the groups of earliness (in the range from somewhat over 6 to nearly 13\%), with a slightly higher variation of those traits for tubers of the early cultivars (except for bioethanol yield) as compared to the late cultivars. Sawicka and Pszczółkowski (2017), on the other hand, demonstrated a lower variation in the yields of edible potato in the group of very early cultivars than in the group of early cultivars. Variation of the analysed traits of tubers and of the resistance to diseases varied, in the range from $4.92 \%$ for eye depth for early cultivars to $19.70 \%$ for resistance to potato blight, and from $6.91 \%$ for tuber shape regularity for late cultivars to $19.49 \%$ for resistance to virus L. Sawicka and Pszczółkowski (2017) point out that apart from the genetic variation, the variation of potato traits is affected also by the environmental variation (soil environment, precipitations and temperature). Sawicka et al. (2011) and Sawicka and Pszczółkowski (2017) demonstrated, in addition, that the genetic factor determines the most strongly the phenotypic variation of dry matter content, and the habitat factors determine the most strongly the phenotypic variation of tuber yield and dry matter yield, while the interaction of cultivars and years determines the most strongly the yield of dry matter. Similar results, with the use of a model of variance components, were obtained by Bombik et al. (2007).

Analysing the relationships among the traits of starch potato (Tab. 8), positive correlations (with increase in the value of one trait there is an increase in the value of another) were demonstrated, both for the early and the late cultivars, between tuber yield and the following: dry matter yield, starch yield, and bioethanol yield ( $\mathrm{r}$ from 0.667 to 0.871). Similar results were obtained by Świeżyński (1977) and by Bombik et al. (2007). A positive correlation was also noted between tuber yield and tuber shape regularity in the medium late and late cultivars. For all the groups of earliness, dry matter yield was positively correlated with starch yield, bioethanol 
Table 8. Matrix of coefficients of simple correlation among analysed traits of starch potato cultivars

\begin{tabular}{|c|c|c|c|c|c|c|c|c|c|c|c|c|c|}
\hline \multicolumn{14}{|c|}{ Very early and early potato cultivars } \\
\hline $\begin{array}{c}\text { Trait } \\
(\text { variable })^{1 /}\end{array}$ & $\mathrm{X}_{1}$ & $\mathrm{X}_{2}$ & $X_{3}$ & $\mathrm{X}_{4}$ & $\mathrm{X}_{5}$ & $X_{6}$ & $X_{7}$ & $\mathrm{X}_{8}$ & $\mathrm{X}_{9}$ & $\mathrm{X}_{10}$ & $\mathrm{X}_{11}$ & $X_{12}$ & $X_{13}$ \\
\hline $\mathrm{X}_{1}$ & 1 & -.462 & $.787^{* 21}$ & .156 & $.871^{*}$ & $.797^{*}$ & .490 & -.456 & 240 & .161 & .075 & .048 & .263 \\
\hline $\mathrm{X}_{2}$ & -.462 & 1 & .182 & .445 & -.138 & -.442 & .148 & -.215 & -.242 & -.284 & .464 & 137 & .274 \\
\hline$X_{3}$ & $.667^{*}$ & * .350 & 1 & .488 & $.872^{*}$ & $.577^{*}$ & $.660^{*}$ & $-.644^{*}$ & .107 & -.018 & .402 & .150 & .479 \\
\hline$X_{4}$ & -.351 & $1.889^{*}$ & .370 & 1 & $.618^{*}$ & .220 & .265 & -.120 & .483 & $-.666^{*}$ & * $.618^{*}$ & * .177 & $.624^{*}$ \\
\hline $\mathrm{X}_{5}$ & $.756^{*}$ & * .161 & $.931^{*}$ & .346 & 1 & $.737^{*}$ & .512 & -.416 & .424 & -.209 & .374 & .111 & .526 \\
\hline $\mathrm{X}_{6}$ & $.830^{*}$ & ${ }^{*}-.031$ & $.859^{*}$ & .139 & $.939^{*}$ & 1 & .158 & -.439 & .178 & .247 & .146 & .202 & .430 \\
\hline$X_{7}$ & .538 & .328 & $.837^{*}$ & .275 & $.734^{*}$ & $.697^{*}$ & 1 & -.364 & .194 & -.064 & .332 & .089 & .037 \\
\hline $\mathrm{X}_{8}^{\prime}$ & -.448 & 3. .238 & -.260 & .044 & -.402 & -.416 & -.083 & 1 & .049 & -.106 & -.157 & -.045 & -.218 \\
\hline $\mathrm{X}_{9}$ & .242 & .146 & .405 & .196 & .388 & .399 & .433 & -.513 & 1 & $-.741^{*}$ & * .170 & -.117 & .098 \\
\hline$X_{10}$ & -.488 & 3.199 & -.327 & .366 & -.236 & -.286 & -.515 & -.006 & -.028 & 1 & -.310 & .252 & -.142 \\
\hline$X_{11}$ & .475 & -.213 & .316 & -.273 & .274 & .162 & .159 & -.361 & .001 & -.276 & 1 & .417 & .434 \\
\hline$X_{12}$ & $.597^{*}$ & * -.342 & .344 & -.448 & .296 & .384 & .269 & .230 & -.318 & -.481 & .341 & 1 & $.653^{*}$ \\
\hline$X_{13}$ & .386 & -.292 & .141 & -.409 & .097 & .108 & .041 & .155 & -.468 & -.506 & .449 & $.852^{*}$ & 1 \\
\hline \multicolumn{14}{|c|}{ Medium late and late potato cultivars } \\
\hline
\end{tabular}

yield and resistance to virus $Y$. In the case of the early cultivars, dry matter yield was also negatively correlated with resistance to leafroll virus (PLRV) (cultivars with higher yields were less resistant to virus L), and in addition, in cultivars from that group of earliness the following significant correlations were noted: a negative correlation between percentage starch content and resistance to common scab and a positive correlation with tuber size (larger tubers were characterised by a higher starch content) and eye depth, and also positive correlations with starch yield and bioethanol yield (with increase in starch content there was an increase of starch yield and bioethanol yield). In the case of medium late and late cultivars, a positive correlation was demonstrated between percentage content of dry matter and starch, and starch yield was positively correlated with bioethanol yield and resistance to virus $\mathrm{Y}$ (cultivars more resistant to virus $\mathrm{Y}$ were characterised by higher starch yield and bioethanol yield). Both early and late cultivars with regular tuber shape had also smaller eye depth (positive coefficients o correlation between those traits of 0.653 and 0.852 , respectively, for those groups of cultivars). These relationships are similar to those obtained by Świeżyński (1977), Styszko et al. (2001), Styszko (2004), Prośba-Białczyk (2008), and Kołodziejczyk et al. (2013). Also Styszko and Kamasa (2007) demonstrated that high-yielding cultivars, and more resistant to diseases at the same time, attain higher values of traits of consumption quality.

The total yield of tubers of very early and early cultivars of starch potato, in the multiple regression equations presented in Table 9, was significantly determined by the following traits (variables): dry matter content (variable $\mathrm{X}_{2}$ ), resistance to virus $\mathrm{Y}\left(\mathrm{X}_{7}\right)$ and eye depth $\left(\mathrm{X}_{13}\right)$. The partial coefficient of regression at variable $\mathrm{X}_{2}$ was negative, which means that with an increase of dry matter content by $1 \%$ the 
Table 9. Equations of multiple regression describing utility features of starch potato cultivars

\begin{tabular}{|c|c|c|}
\hline $\begin{array}{l}\text { Analysed trait } \\
\text { (variable) }\end{array}$ & Multiple regression equation & $\begin{array}{c}\text { Coefficient of } \\
\text { determination } \\
(\%)\end{array}$ \\
\hline \multicolumn{3}{|l|}{ Total yield of tubers } \\
\hline - early cultivars & $\mathrm{Y}=57.92-1.61^{* 1 /} \mathrm{X}_{2}^{2 /}+1.75^{*} \mathrm{X}_{7}-1.57 \mathrm{X}_{8}-4.16 \mathrm{X}_{12}+7.68^{*} \mathrm{X}_{13}$ & 87.0 \\
\hline - late cultivars & $\mathrm{Y}=11.23-1.39^{*} \mathrm{X}_{2}+1.07 \mathrm{X}_{4}+3.01^{*} \mathrm{X}_{7}-1.63^{*} \mathrm{X}_{8}+5.10^{*} \mathrm{X}_{12}$ & 91.4 \\
\hline $\begin{array}{l}\text { Dry matter content } \\
\text { - early cultivars }\end{array}$ & $\mathrm{Y}=2817-034^{*} \mathrm{x}+082^{*} \mathrm{x}+049 \mathrm{X}-088 \mathrm{X}-070 \mathrm{X}+$ & \\
\hline - late cultivars & $\begin{array}{l}Y=28.1 /-0.34 X_{1}+0.82 X_{4}+0.49 X_{7}-0.88 X_{8}-0.10 X_{9}+ \\
0.14 X_{11}\end{array}$ & 86.9 \\
\hline & $\mathrm{Y}=-2.23+1.35^{*} \mathrm{X}_{4}+0.46 \mathrm{X}_{8}$ & 82.9 \\
\hline $\begin{array}{l}\text { Starch content } \\
\text { - early cultivars }\end{array}$ & $\mathrm{Y}=14.55-1.13^{*} \mathrm{X}_{10}+0.48 \mathrm{X}_{11}-1.07 \mathrm{X}_{12}+2.38^{*} \mathrm{X}_{13}$ & 82.8 \\
\hline $\begin{array}{l}\text { - late cultivars } \\
\text { Bioethanol yield }\end{array}$ & $\mathrm{Y}=0.86+0.10 \mathrm{X}_{1}+0.59^{*} \mathrm{X}_{2}+0.58 \mathrm{X}_{10}-0.76 \mathrm{X}_{12}$ & 88.2 \\
\hline - early cultivars & $Y=-2613.18+158.39^{*} X_{1}-193.51 X_{7}+385.31 X_{12}$ & 74.9 \\
\hline - late cultivars & $\mathrm{Y}=-873.75+103.90^{*} \mathrm{X}_{1}+132.11^{*} \mathrm{X}_{4}-115.00^{*} \mathrm{X}_{11}$ & 94.4 \\
\hline
\end{tabular}
in Material and Method

yield of tubers will be lower by 1.67 ton per hectare, with the assumption that the remaining parameters will remain at a stable level. At variables $X_{7}$ and $X_{13}$ the coefficients of regression were positive, which means that the tuber yield of the early cultivars increases with an increase of resistance of the cultivars to virus $Y$ and in cultivars with shallower eyes. In the case of total yield of tubers of the medium late and late cultivars, significant coefficients of regression were obtained at the following variables: negative for dry matter content $\left(\mathrm{X}_{2}\right)$, positive for resistance to virus $\mathrm{Y}\left(\mathrm{X}_{7}\right)$, negative for resistance to virus $L\left(X_{8}\right)$, and positive for tuber shape regularity $\left(X_{12}\right)$. The variables in those equations explained the variation of yielding, measured with the coefficient of determination, in from $87.0 \%$ for the early cultivars to $91.4 \%$ for the late cultivars. Dry matter content of the early cultivars was described significantly by 2 variables: negatively by the total yield of tubers $\left(\mathrm{X}_{1}\right)$ and positively by the content of starch $\left(\mathrm{X}_{4}\right)$. This means that with an increase of the total yield of tubers the content of dry matter decreases, and an increase in starch content is reflected in an increase of dry matter content in tubers. Dry matter content in tubers of the late cultivars was significantly and positively determined, as in the late cultivars, by the content of starch $\left(\mathrm{X}_{4}\right)$. For both groups of earliness, the values of the coefficient of determination were higher than $80 \%$. Starch content in tubers of the early cultivars was significantly modified as follows: negatively by resistance to common scab $\left(\mathrm{X}_{10}\right)$, which means that with an increase of resistance to common scab there is a decrease of starch content in tubers, and positively with eye depth $\left(\mathrm{X}_{13}\right)$, while in late the late cultivars, only positively with increase of dry matter content $\left(\mathrm{X}_{2}\right)$. Regression equations constructed for starch content explained its variation, as in the case of dry matter content, in more than $80 \%$. Bioethanol yield of the 
early cultivars depended significantly only on variable $X_{1}$, i.e. tuber yield. In the case of the late cultivars, bioethanol yield depended also on variable $X_{1}$, and also positively on starch content $\left(\mathrm{X}_{4}\right)$ and negatively on tuber size (variable $\mathrm{X}_{11}$ ). Regression equations for bioethanol yield explained the variation of that trait in $74.9 \%$ for the early cultivars and in up to $94.4 \%$ for the late cultivars. The presented equations support the relationships described earlier (Tab. 8), and they also fulfil the criterion of coincidence (Draper and Smith 1973), i.e. the agreement of signs at the significant partial coefficients of regression with the signs of the coefficients of correlation. That agreement allows logical interpretation of the presented correlations among the tuber traits.

\section{CONCLUSIONS}

1. The analysed starch potato cultivars, both very early and early ones and medium late and late ones, were characterised by similar utility features such as dry matter content and starch content. A higher total yield of tubers, and in effect a higher dry matter yield, starch yield and bioethanol yield, was produced by the late cultivars, in relation to the early cultivars. The variation of those traits, measured with the value of the coefficient of variation, was similar for both of the groups of earliness.

2. The average value of resistance of the early and late cultivars to diseases, e.g. to virus $\mathrm{Y}$, virus $\mathrm{L}$ and to common scab, was similar, with the exception of potato blight, to which the late cultivars were more resistant.

3. In both groups of earliness, tuber shape traits, i.e. shape and shape regularity and eye depth, were at a comparable level and they were characterised by small variation. A somewhat greater variation was characteristic of tuber size, especially in the case of the late cultivars.

4. A number of correlations were demonstrated, estimated on the basis of the coefficient of simple correlation, among the analysed utility traits and quality traits of tubers of the starch potato cultivars. Positive correlations were noted between the total yield of tubers and dry matter yield, starch yield and bioethanol yield, between dry matter yield and starch yield, bioethanol yield and resistance to virus $Y$ and between shape regularity and eye depth. Negative correlations appeared only in the group of very early and early cultivars, between dry matter yield and resistance to virus $\mathrm{L}$, and between starch content and resistance to common scab.

5. Multiple regression analysis allowed to determine that the total yield of tubers in the very early and early cultivars, as well as in the medium late and late cultivars, depended significantly on dry matter content and on resistance to virus $\mathrm{Y}$. Dry matter content was significantly determined by starch content, and bioethanol yield - mainly by the total yield of tubers. Those correlations allowed to explain the variation of those traits in the range from nearly $75 \%$ for bioethanol yield in the late cultivars to over $90 \%$ for the total yield and bioethanol yield in the late cultivars. 


\section{Conflict of interest: The Authors does not declare conflict of interest.}

\section{REFERENCES}

Bach S., Yada R.Y., Bizimungu B., Fan M., Sullivan J.A., 2013. Genotype by environment interaction effects on starch content and digestibility in potato (Solanum tuberosum L.). J.Agric. Food Chem., 61(16), 3941-3948, https://doi.org/10.1021/jf3030216.

Bogucka B., 2014. Effect of different mineral fertilization technologies on the size of starch granules in potato. Starch/ Stärke, 66, 1-6, https://doi.org/10.1002/star.201300242.

Bogucka B., Cwalina-Ambroziak B., 2016. Mineral fertilization on selected components of tubers of different potato cultivars. Zesz. Probl. Post. Nauk Rol., 585, 13-23.

Bogucka B., Cwalina-Ambroziak B., Zięba T. 2010. The effects of varied soil and foliar mineral fertilization levels in the production of high-starch potatoes. Pol. J. Natur. Sci., 25(3), 215-228, https://doi.org/10.2478/v10020-010-0019-5

Bombik A., Rymuza K., Markowska M., Stankiewicz Cz., 2007. Variability analysis of selected quantitative characteristics in edible potato varieties. Acta Sci. Pol., Agricultura, 6(3), 5-15.

Bombik A., Wolska A., 2004. Selected factors shaping the economic effect of potato production (in Polish). Acta Sci. Pol., Oeconomia, 3(2), 17-26.

Characteristics of the Polish National List of Potato Varieties (in Polish), 2016. Wyd. IHAR PIB, Oddział Jadwisin, $43 \mathrm{~s}$.

Descriptive List of cultivars, crop plants (in Polish), 2016. Wyd. COBORU, Słupia Wielka.

Draper N.R., Smith H., 1973. Applied regression analysis (in Polish). PWN, Warszawa.

Edwards C.G., Englar J.W., Brown C.R., Peterson J.C., Sorensen E.J., 2002. Changes in colour and sugar content of yellow-fleshed potatoes stored at three different temperatures. Am. J. Potato Res., 79, 49-56, https://doi.org/10.1007/BF02883523

Fontes P.C.R., Braun H., Busato C., Cecon P.R., 2010. Economic optimum nitrogen fertilization rates and nitrogen fertilization effect on tuber characteristic of potato cultivars. Potato Res., 53, 161179, https://doi.org/10.1007/s11540-010-9160-3

Hertog M.L.A., Putz B., Tijskens L.M.M., 1997. The effect of harvest time on the accumulation of reducing sugars during storage of potato (Solanum tuberosum L.) tubers: Experimental data described, using a physiological based, mathematical model.. Potato Res., 40(1), 69-78, https:// doi.org/10.1007/BF02407563

Jansen G., W. Flamme W., Schüler K.,Vandrey M., 2001. Tuber and starch quality of wild and cultivated potato species and cultivars. Potato Resch., 44(2), 137-146, https://doi.org/10.1007/ BF02410100

Kamasa J., 2002. Potato (in Polish). In: Descriptive List of cultivars, 2002, Wyd. COBORU, Słupia Wielka, 121-149.

Kamasa J., Borys J., 1991. Estimation of economic value of potato cultivars in Poland (in Polish). In: Synthesis of input materials for potato breeding, accomplishments and perspectives. Ed. I. Ziemn., Bonin, 127-131.

Kołodziejczyk M., Szmigiel A., Kulig B., Oleksy A., 2013. Estimation of yields, chemical composition and quality of tubers of selected cultivars of starch potato (in Polish). Inż. Rol., 1, 28-41.

Leszczyński W., 2000. Criteria for the estimation of quality of edible potato and starch potato (in Polish). In: Edible and industrial potato and its processing. Konf. Nauk., Polanica Zdrój, 41-49.

Leszczyński W., 2001. Variation of starch properties (in Polish). Przemysł Spożywczy, 3, 38-39.

Lewosz J., 1985. Selected topics in potato biochemistry (in Polish). In: The Biology of Potato. PWN, Warszawa, 120-312. 
Mystkowska I., Baranowska A., Zarzecka K., Gugała M., Lipiecki M., 2016. Profitability of potato production for the starch industry at a private farm (in Polish). Zesz. Nauk. UPH, Siedlce, Administracja i Zarządzanie, 110, 103-112.

Niederhauser J.S., 1993. International cooperation and the role of potato in feeding the world. Am. Potato J., 70(5), 385-403, https://doi.org/10.1007/BF02849119

Nowacki W., Czerko Z., Goliszewski W., Jankowska J., Lutomirska B., Trawczyński C., Zarzyńska K., 2013. Methodology of integrated potato production (in Polish). Wyd. Państwowa Inspekcja Ochrony Roślin i Nasiennictwa, Warszawa.

Prośba-Białczyk U., 2008. Starch potato production (in Polish). Zesz. Probl. Post. Nauk Rol., 530, 43-52.

Rembeza J., 2004. Changes in potato production and use in Poland on the background of EU countries (in Polish). Wieś Jutra, 2, 25-26.

Roztropowicz S., 1993. Principles of starch production cultivation for processing into starch (in Polish). In: Potato production. Technology - Economics - Marketing. Ed. I. Ziemn., Bonin, 85-89.

Rykaczewska K., 2010. Studies on the physiological foundations of potato productivity (in Polish). Mat. Konf. Nauk. nt. Tradycja i nowoczesność w produkcji ziemniaka, Jadwisin, 21-22.

Rymuza K., Radzka E., Lenartowicz T., 2015. The effect of environmental conditions on starch content in tubers of medium early potato cultivars (in Polish). Acta Agroph., 22(3), 279-289.

Sawicka B., Michałek W., Pszczółkowski P., 2011. Determinants of yielding potential of merium late and late potato cultivars in the conditions of central-eastern Poland (in Polish). Biul. IHAR, 259, 219-228.

Sawicka B., Pszczółkowski P., 2017. Phenotypic variation of yield and yield structure of very early and early potato cultivars (in Polish). Fragm. Agron., 34(1), 76-91.

Styszko L., 2004. Breeding of starch potato cultivars with high utility parameters (in Polish). Biul. IHAR, 232, 275-283.

Styszko L., Kamasa J., 2007. Correlation between the resistance of potato cultivars to pathogens and the taste of tubers in years with different levels of yields (in Polish). Prog. Plant Prot., 47(2), 343-347.

Styszko L., Modzelewski T., Kamasa J., Majewski A., 2001. Relations between the resistance of potato cultivars to major pathogens and starch content in tubers and its yield (in Polish). Mat. XXXXI Sesji Nauk. IOR, Poznań, 647-649.

Świeżyński K., 1977. Potato breeding (in Polish). In: Potato breeding and seed production. PWRiL, Warszawa, $230 \mathrm{~s}$.

Trawczyński C., 2016. The effect of cultivar and weather conditions in the vegetation season on the content of selected nutrients and anti-nutrients in potato tubers (in Polish). Acta Agrophysica, 23(1), 119-128.

Trętowski J., Wójcik A.R., 1991. Methodology of agricultural experiments (in Polish). Wyd. WSRP Siedlce.

Zarzecka K., 2014. Technology of potato cultivation in the sustainable farming system (in Polish). Biul. IHAR, 272, 113-127.

Zgórska K., Frydecka-Mazurczyk A., 2000. The effect of conditions during vegetation and of storage temperature on quality traits of potato destined for processing (in Polish). Biul. IHAR, 213, 239-251.

Zgórska K., Grudzińska M., 2010. Suitability of potato cultivars for food processing (in Polish). Ziemn. Pol., 3, 1-3.

Zgórska K., Grudzińska M., 2012. Changes of selected quality traits of potato tubers in the course of storage (in Polish). Acta Agroph., 19(1), 203-214. 